ISSN 1014-4874

DOI : http://dx.doi.org/10.4314/rj.v26il.7

\title{
The effects of credit policy on bank performance: Evidence from selected Rwandan Commercial banks
}

Vincent Byusa \& David Nkusi

\begin{abstract}
The post Genocide Rwanda's financial sector has changed drastically, and banks' soundness and performance has considerably improved since 2005. Further liberalization of financial sector has facilitated development of a capital market and non-banking financial institutions with entry of new private and foreign banks. Yet, the collective performance of the banking sector in helping the country to achieve its economic growth objectives remains an unexamined aspect. The aim of this paper is to investigate the effects of credit policy on bank performance using data on selected Commercial Banks.

Using a triangulation of methods such as quantitative data collection, questionnaire, and review of the existing literature, the paper evaluates the banking sector performance: its deepening over time, profitability, and efficiency in the light of post-liberalisation policies.

The results obtained indicate that the Rwanda's commercial banks are getting vibrant. They tend to increase their accounts, to attract more customers and ameliorate their financial indices, thereby maximizing their profits. However, inadequate competition in the banking system has led to high spreads. Banks have unusually high and increasing average interest rate spreads and interest rate margins showing both highly poor competition and inefficiency. Bad debts still exist though declining and therefore banks should continue to improve their lending policies. The findings imply that Rwanda can accelerate its economic growth by improving its financial systems and vice versa.
\end{abstract}

Keywords: Rwanda, Commercial Bank, Bank Performance, Bank profitability, Bank efficiency, credit policy.

\section{Introduction}

When conflict closes the banking system as in Rwanda during the 1994 Genocide, its reopening becomes a priority. Otherwise the resumption of normal economic activities, requiring the clearing of domestic and foreign payments and use of deposit accounts will severely be impeded. The government of Rwanda encouraged the reopening of banks to not only mobilise funds for personal finance but also for business development. This 
was done through several reforms which took place in 1995 onwards. Such reforms have enabled commercial banks to impact their clients positively.

In this paper, the authors' goals are to investigate the efficiency and effectiveness of credit policies in commercial banks in Rwanda; assess the adequacy of Commercial banks loan advancement; and examine the relationship between credit policies and performance of loan advancement. Credit policy as a set of guidelines can be the cause of poor performance. It is of great importance to evaluate a policy to know if it is on the right track or if it is a deviation from the bank's goals.

\section{Material and methods}

With an architectural policy perspective, it was necessary to have some insights into the impact of credit policies on bank performance in Rwanda through a questionnaire, and put this in relation to quantitative data. To get a broader picture and to understand the quantitative data, it was important to allow staff of the selected banks (Fina Bank - Rwanda, Bank of Kigali (BK), and Commercial Bank of Rwanda (BCR)) to formulate their perceptions and experiences with their own words. The qualitative data was used as a guideline in the analysis of quantitative data. The two approaches used in the research project were thus complimentary to a desk review of existing literature on the subject.

\section{Results and discussion}

Out of 24 respondents 6 were females and 18 were male. The majority of the respondents were found to be in the age group of 21-49 years implying that bank's workforce is still youthful with a work experience of 3 years only. The work force is relatively well educated. 18 of the 24 respondents had bachelors' degrees while 5 of them had master's degree.

All 3 banks have adequate credit policies which are reflected in their banks' mission, goals, credit responsibility, collection policy and credit evaluation policies ranging from Car loans, personal loans, overdraft and mortgage at interest rate ranging from $17.25 \%$ to $20 \%$ per year. Loan application period range from 1 day to 10 days depending on the type of loan. The maximum repayment period is 20 years even it was reduced to 5 years during the 2008/2009 international credit crunch. Evidences also show that six factors have influenced credit policy development and formulation in Rwanda, namely capital position, earnings, deposit variation, good macroeconomic environment, response to shocks, improved competitive position and experience of loan officers. 
To limit credit risk, all the 3 banks assess the customer's credit worthiness with the help of 5Cs namely: Character, Capacity, Capital, Collateral and Conditions. This indicates that each type of loan application must go through loan description process, preferred maturity period, indication on maximum allowable amount, and provide an insurance cover. The loan should generally be protected by collateral and the channel of approval should be documented and approved by the Board of Directors.

To avoid bad debts the National Bank of Rwanda (BNR) require banks to make provisions on their profits for bad debts. This is because poor credit policies and short-sighted credit analysis can have a big negative impact on the banks profitability and hence performance.

Overall, National bank of Rwanda data reveals that as interest income increased, provision for bad debts went in the opposite direction i.e. was declining which is an indication of the efficiency of credit policies as applied by commercial bank. Such efficient credit policies obviously lead to commercial banks profitability.

\section{Conclusion and Recommendation}

Credit policies indeed affect the performance of commercial bank. All selected banks have effective and efficient credit policies. Nevertheless, bad debts still exist and banks should continue to improve their lending policies and should continue to train staff to the highest expertise. Interest rate should be reduced and much with the prevailing inflation rate.

\section{References}

\section{Articles}

1. Bradley T. Samples (2005); Economic Decision-Making as a Function of Risk Tolerance: The Case of Rwanda.

2. Darryl R. Francis (1971),Speech by President of the Federal Reserve Bank of St. Louis; Monetary Policy as a Background for Commercial Bank Credit Policy .St Louis,USA.

3. Etienne Ntaganda; (2006); The impact of implementing credit risk management on the bank's loan portfolio and Financial statements: the case of Bancor S.A.; Kigali Rwanda.

4. National Bank of Rwanda, Annual report various issues

5. Purna Chandra Adihikali (2007); Compliance of commercial bank under Base I Criteria and other regulatory norms in Nepal: 
Comparative case study of HIMALAYAN BANK Limited and NEPAL Arab Bank limited.

6. Tony Addison, Alemayehu Geda Philippe le Billon and S. Mansoob Murshed (2001); Financial Restructuring in Conflict and 'Post Conflict Economies' Discussion paper No. 2001/90, United Nations University .

7. Experts commend Rwanda's financial sector progress. The New Times. May 27, 2010. KIGALI RWANDA.

8. Meena Pandey, (2001) Business Planning and Policy, Second Edition, Himalaya Publishing House.

9. Morton Glantz, (2003) Managing bank risk; an introduction to broad case credit Engineering, academic press; California, USA. 